\title{
CARD INDEX OF FORMER LATVIAN SSR KGB AGENTS: TRAUMA AND THE PATH TO PUBLIC RECONCILIATION
}

\author{
Uldis Krēsliňs \\ Department of 20th Century Research \\ Institute of Latvian History, University of Latvia, Latvia \\ uldis.kreslins@lu.lv
}

\begin{abstract}
In August 1991, the Republic of Latvia took over the documents of the former Latvian SSR KGB, including the card index of KGB agents. At that time, by postponing the card index publication, the political authorities made the issue of former KGB agents a hostage of their political interests. Discussion on the fate of the card index continued in Latvian public sphere over the next 27 years. The stance of the political elite, which found support in some groups of society, was opposed to the publication of the card index, being concerned about a possible witch-hunt and psychological trauma of the people mentioned in the card index as well as their relatives. However, as a result of public pressure, after lengthy indecision, the card index was made public in December 2018.

Unfortunately, the publication of the card index has offered only a formal solution to the issue of the former KGB agents, and the expected results have been achieved from the aspect of neither historical truth nor public reconciliation. Only a small number of people mentioned in the card index have admitted the fact of their cooperation and just a few have expressed public regret. In turn, after 27 years of political elite's hesitancy, most of the KGB persecution victims accepted the publication of the card index in silence. However, it is clear that denial and silence are not the way to public reconciliation and comprehension of trauma. Those few attempts to make one's experience public show that in today's situation people can seek reconciliation only with themselves and within themselves.
\end{abstract}

Keywords: card index of former KGB agents, 'Cheka Bags', Latvian Government Commission for KGB Research, Latvian SSR, trauma, victims of the persecution of the KGB

In December 2018, 27 years after the restoration of the country's independence, the card index of the former agents of the Committee for State Security (KGB) of the Latvian Soviet Socialist Republic (Latvian SSR) was published. This was an event that had been prepared and debated in Latvian society for a long time. There were several expectations in society associated with the 
publication of the card index; first of all, the hope that this would put an end to vague guesses and the legacy of the Soviet regime. At the same time, in the future, the publication of the card index could have allowed the consolidation of certain values in society (Fedosejeva 2019), and, first and foremost, the belief in justice and openness. Today, more than a year after the card index was made public, we can say that some of these expectations have been fulfilled, but the principal assessment of the recent past has not taken place, and the expected results have not been achieved, neither in terms of historical truth, nor public reconciliation.

The main stumbling block, in this case, is that both the political authorities of Latvia and the Latvian society lack the will to clearly formulate their position. The uncertainty of the political authorities is, first of all, determined by the complex conflict between the condemnation of collaborationism and the fact that the card index of the former KGB agents contains the names of several people who belonged to the country's political elite in the 1990s. The restraint of society, in turn, is determined by a wider range of circumstances. The main thing here is the historical experience of society. Latvian society in the twentieth century experienced a number of dramatic historical upheavals: two world wars, two occupations, and two mass deportations. This has made the experience of trauma a permanent and even routine element of society's collective memory, accompanied by a number of features. First, these many shocks have caused some degree of indifference and alienation in the public opinion, not only as a condition for physical self-preservation, but also as a condition for maintaining mental health. Secondly, the frequent change of political regimes and, consequently, the model of heroes/traitors (perpetrators/victims) not only split society, but also fragmented its historical memory, so that in many cases it is difficult to talk about a unified public view of the past. ${ }^{1}$ This state of affairs is further complicated by the national heterogeneity of Latvian society, in which different national groups have distinctly different views on events. ${ }^{2}$ Due to all the mentioned circumstances, a situation has arisen in which the issue of the former KGB agents has found only a formal solution with the publication of the card index, but its balanced evaluation has not occurred.

The aim of this study is to find out how substantial the trauma discourse was in the discussions before the publication of the card index and in public judgments already after the publication, and why the publication of the card index failed to bring about public reconciliation. To answer these questions, on the one hand, it is salient to trace the major conflicts of opinions and arguments that were expressed in public discussions prior to the publication of the card index. The focus here is on the balance between political and emotionalpsychological arguments, such as justice, regret, purification, and forgiveness, 
which were used in these discussions. This ratio, albeit conditionally, would allow us to judge to what extent Latvian political authorities ${ }^{3}$ and society as a whole were ready to accept the traumatic experience of an individual and a certain group of society in the common stance of society. On the other hand, it is no less important to find out how the people whose names were mentioned in the card index positioned themselves and their former activities after the card index was made public, and how the revelations of former agents were perceived in society. Researching these various aspects, the study seeks to confirm the hypothesis that the decisions of political authorities about the fate of the card index of the former KGB agents were dictated by political interests, using other arguments, including trauma arguments, only to cover up these interests, whereas the trauma of this historical experience in society's collective memory is not yet fully conscious.

In order to understand the various arguments used in the discussions, analysed in this study, it is necessary - slightly ahead of the sequence of their presentation - to agree on some factual issues and terminology used. Firstly, the documents seized from the former Latvian SSR KGB were in fact several sets of documents, the most important of which were the alphabetical card index of agents and the registration logs of agents. Data on the number of agent cards in the alphabetical card index had changed several times over time; ${ }^{4}$ when the card index was made public, it turned out that it contained more than seven thousand agent cards. In addition to agents' personal data and the chosen nickname, each card also contains information about the specific department of the KGB that had recruited the agent. Unfortunately, in most cases there is a lack of documentary evidence of the agents' specific actions (or inaction), which makes judgement impossible. Secondly, when assessing the activities of the former KGB agents, it is necessary to take into account the fact that the tasks of the KGB covered both the internal security and external intelligence functions of the Soviet Union (USSR). Therefore, in the card index of the former KGB agents there are both external intelligence agents, whose status was usually associated with 'cloak-and-dagger' heroes, and regular 'kitchen conversations' reporters, most often associated with snitches. And finally, all the people whose names are mentioned in this study as former Latvian SSR KGB agents, are documented according to the published card index of agents, without claiming their cooperation with the KGB to be an indisputable fact. 


\section{TRAUMA PROBLEMATICS AND RESEARCH APPROACH}

The issues of the agents of the state security of the former Soviet regime and the evaluation of their activities have remained in the public spotlight throughout the years after the restoration of Latvia's independence. The topicality of this issue is reflected in scientific research and media publications, as well as in several works of art. Among the scientific studies the publications by the Latvian Government Commission for KGB Research can be noted. Jānis Taurēns's research on public polemics over the KGB's documentary heritage deserves more attention here (Taurēns 2015). The list of works of art includes the documentary film Lustrum (2018), the Latvian television film Atmodas labirintā (In the Labyrinth of Awakening) (2020), and the New Riga Theatre production Vēstures izpētes komisija (History Research Commission) (2019). ${ }^{5}$

The present study differs from the previous ones in that it is the first work that attempts to analyse the issue of the relationship between the former Latvian SSR KGB agents and victims of persecution of the KGB from the trauma perspective. The difficulties here are, above all, caused by the fact that the trauma problematics in Latvia is a new research topic, and only in 2019 the first monograph dedicated to this issue was published, titled Totalitārisma traumu izpausmes Baltijas prozā (Manifestations of Totalitarianism Traumas in Baltic Prose) (Gūtmane 2019). However, the problem of trauma has been in the focus of researchers in the world for a long time and the number of works dedicated to it is significant. In the context of this study, special mention should be made of the study by Gilad Hirschberger (2018), in which differences of opinions in the perception and identification of collective trauma by victims and perpetrators are presented in a concentrated form. However, the number of studies dedicated to the activities of the former agents of state security in the so-called Soviet Bloc states in Eastern Europe is not extensive. The exception is Germany, where the dramatic consequences and victims of the former Stasi (state security service of the German Democratic Republic) actions have received more attention, coining a new concept in psychiatry: the Stasi persecution syndrome.

The main factor that has determined my approach to this issue is three major limitations: the very small number of published memories, the stingy and impassive, even 'dry' description of human experiences in these memories, and, finally, the complex and multifaceted understanding of trauma in this case. In order to avoid misunderstandings, it is important to emphasize that the reference to the small number of published memories refers to those publications which cover the activities of the Latvian SSR KGB agents, rather than the activities of the KGB in general, for which the number of dedicated memories and scientific research is much higher. 
In the list of these memories, from the victims' point of view, those of the former Prime Minister of Latvia, Māris Gailis, deserve special attention: he briefly describes the unsuccessful attempt of his recruitment in 1986 and the subsequent persecution, carried out by the KGB, not only by questioning his colleagues, but also by spreading various slanderous rumours about him (Gailis 1997: 174-176). What makes his story meaningful from the point of view of our interest is the KGB's persecution formulated in it, pointing out that this often took place behind a person's back and they did not even know about it. Also, a biographical work dedicated to the well-known Latvian dissident Gunārs Astra (1931-1988) can be mentioned here (Ruks 2011).

The list of narratives of the former KGB agents includes the memories of Jānis Mazulāns, who fled to Sweden in 1960, and the autobiographical story of Juris Dimitris, a former double agent of the USSR KGB and the Federal Intelligence Service (BND) of the Federal Republic of Germany, about his activities in the 1960s. Their memories, although different in content, are united by a similar view of cooperation with the KGB. Mazulāns, describing his emotional experiences when agreeing to the cooperation proposal - to this "dirty and shameful work" - immediately adds that he could not reject this offer and "no one allowed him to give it up" (Melnais 1993: 7).On the other hand, Dimitris, who clearly postulated in the introduction to his memories that everyone has their own morality and he likes "pragmatic, rational morality" (Dimitris 2019: 10), remembers how he did not pass the competition at the Law Faculty of the State University of Latvia at the beginning of his agent career and complained about it to his KGB curator, after which it turned out that his name had "miraculously" appeared in the list of admitted students (ibid.: 33-34). The judgments of both these former KGB agents clearly show that they accepted cooperation with the KGB as a precondition for their career opportunities and certain privileges, including the possibility to travel abroad; this cooperation did not seem to be impossible or unacceptable to them, but they rather saw it as an understandable (and inevitable) choice at that time.

However, there were more than two sides in the model of relations between KGB agents and victims of persecution by the KGB. A clear example here is the story of musician, poet, and painter Valdis Atāls (real name Vladimirs Šatrovskis): arrested for political reasons and convicted in the late 1970s under the Criminal Code article on banditry, in imprisonment he agreed to cooperate with the KGB as an agent (Atāls 2018). His story, in which the entanglements of the Soviet era and complex human choices appear particularly sharply, shows that motives for people's cooperation with the KGB were different. And, at the same time, his judgments about cooperating with the KGB point to one important guideline in evaluating the activities of KGB agents: even in Soviet 
times - no matter how "unfair and immoral the whole system was" - it was everyone's own choice and responsibility to agree or disagree to cooperate with the KGB. ${ }^{7}$

The different human experience in this case makes the comprehension of trauma complex and multi-layered. If we are guided by the concept of trauma that links trauma to deeply disturbing and cataclysmic events that threaten the integrity of the individual, then it must be acknowledged that each of these people had a different and very personal onset of their trauma. In turn, for society as a whole, such trauma was, rather, the publication of the agents' card index, which unexpectedly forced to look from a new perspective at the people mentioned in the card index. In addition, the issue of trauma in this case is even more complex due to complicated relations in the perpetrator/ victim model or what Primo Levi (1959) defines as the 'grey zone': the already mentioned story of Atāls shows that a person could have been in both roles at different stages of life.

However, the main problem is that neither in memories, nor in public discussions about the activities of KGB agents and their evaluation, with a few exceptions, this is not spoken of in the discourse of trauma. Just like individuals, society as a whole also formulates its position mainly through pragmatic intellective arguments and motives, and very rarely talks about it as specific psychological and emotional experience and trauma. By way of illustration, from the descriptions of the activities of eighteen former KGB agents, which were published in a series of articles under the heading "Bags Are Open" on the web platform Delfi after the publication of the card index, only one person named in the agents' reports considered the consequences of the agents' actions 'dramatic'. This impassive pragmatism can be explained by several circumstances. Perhaps, part of the explanation lies in the fact that the persecution carried out by the KGB often remained invisible to the public - in the 1970s-1980s there were no longer deportations or arrests, but broken careers and restrictions on professional activity - and today public opinion considers people who would position themselves as victims of persecution by the KGB losers seeking explanation for their career failures. But perhaps an even more important reason, with rare exceptions, for people's judgments not to formulate the understanding and content of trauma is that there is no such tradition in the Latvian public space of the issue of persecution by the KGB (unlike deportations). Media interest is more focused on the depiction of events than on experiences, so there is a lack of encouragement to express these emotional experiences in public. Using an analogy, we can say that Latvian society is in a 'childish state' as concerns the issue of former KGB agents' activities and the experience of victims of persecution by the KGB: it is clear that society is hurt but does not know how to express 
it in words. Therefore, much remains unsaid and unformulated in these stories and the main trap for the researcher, in this situation, is the temptation to replace the unspoken with their own assumptions.

All of the above creates a certain dualism for the researcher: on the one hand, recognizing that, as a personal affair, trauma of the former KGB agents and KGB persecution victims is unquestionable; on the other hand, we have to admit that the small number of published memories makes it difficult to generalize and systemize these trauma experiences. A significant addition to documenting human memories is several series of articles published in electronic media after the publication of the card index. One of them, which deserves more attention, is a series of articles under the heading "Bags Are Open" on the web platform Delfi, which, based on the published KGB documents, is dedicated to the stories of individual agents and persons mentioned in agents' reports. A similar goal has the interview series "Self-Lustration", in which several wellknown intellectuals recall and explain their relations with the KGB. However, in most cases, these publications, too, preserve the same emotionally meagre assessment of events. This limited amount of specific research material has determined the approach of the present study to the problem of trauma, first by focusing on the reflection of different views and judgments brought about by the publication of the card index of the former KGB agents, and then by looking at the stories of the former KGB agents and victims of the KGB persecution from a phenomenological perspective, noting the signs of trauma experience mentioned in them, but, at the same time, guided by the view that these stories cannot be generalized.

\section{'CHEKA BAGS': A TICKET TO FREEDOM OR PANDORA'S BOX?}

The card index of the former Latvian SSR KGB agents was taken over in August 1991, immediately after the failure of the August Coup and the complete restoration of Latvia's independence (Johansons 2006: 146-150; Miḳelsone 2019a). When the card index was taken over, the agents' cards were displaced in bags, so in later discussions and media publications the card index got a new name: 'Cheka Bags'. It was at this time - during the takeover of the former KGB property and documents - that in great haste and deliberately created chaos, most likely, the first and largest 'cleaning' of the KGB agents' card index took place (Šāberte 2006: 303-313). The least that could be blamed on the Latvian political authorities in this situation was negligence.

The first practical consequences for the use of the card index data followed in 1992. In October 1992, Latvia's 5th Saeima (Parliament of the Republic 
of Latvia) Election Law was promulgated, Article 21 of which required each candidate to sign a statement certifying that he or she is not or had not been a staff member or agent of the KGB (Taurēns 2017: 79). After the parliamentary elections on 5-6 June 1993, the agenda of the Saeima included the issue of five new deputies accused of cooperation with the KGB. Among these five, two names were better known: Edvinns Inkēns was one of the most popular Latvian journalists in the late 1980 s, who produced and hosted the weekly programme "Labvakar" (Good Evening) on the Latvian television, and physician Georgs Andrejevs was the Minister of Foreign Affairs of the Republic of Latvia from 1992. In response to the revelations, on 28 May 1994, Andrejevs published an open letter in the newspaper Diena (The Day). In the letter he acknowledged the fact of cooperating with the KGB, explaining his consent to cooperate with professional career interests (at that time he was the chief anaesthesiologist of the republic); as the main moral justification for his actions, Andrejevs mentioned the fact that the reports he wrote to the KGB concerned only his professional occupation and that he did not write reports about his colleagues (Andrejevs 1994). On 7 June of the same year, Andrejevs resigned as minister and surrendered his mandate of the Saeima deputy. Andrejevs's public confession was accepted as an action worthy of an 'honourable man' by society. The other four new deputies denied the fact of their cooperation with the KGB, and their cases were considered in court. All court proceedings ended with a verdict that no evidence was found of these people's deliberate cooperation with the KGB. These trials marked the beginning of the practice of establishing the fact of cooperation with the KGB through the courts, and over the next ten years, from 1994 to December 2015, the court of first instance heard 298 such cases (Stukāns 2015: 117).

The case of the Saeima's 'five' has actualized the need to adopt a special law for the use of documents of the former KGB. The Law on the Preservation and Use of Documents of the Former State Security Committee and the Establishment of the Fact of Cooperation of Persons with the KGB, adopted by the Saeima on 19 May 1994, set a ten-year term for professional restrictions on former KGB employees and agents, at the same time also determining the secrecy status of the KGB agents' card index.

In the second half of the 1990s and early 2000s, the issue of former state security agents in most Eastern European countries had already been resolved, usually through lustration. Meanwhile, discussions continued in Latvia, using various arguments. Opponents of the publication of the card index, whose opinion coincided with that of the political authorities, pointed out as the main argument that the publication of the card index would divide Latvian society (according to them, the card index was left in Latvia for this purpose), ${ }^{8}$ and 
may become a reason for a witch-hunt. In their judgments, the disclosure of the card index could cause a psychological trauma to the people mentioned in the card index as well as their relatives. The same idea was conceptually expressed in the wording: historical injustice cannot be the cause of new injustice (Veidemane 2019a). In addition, as one more argument, they emphasized the limited significance of the card index data, which does not allow one to reliably judge the specific role and activities of each agent. ${ }^{9}$ Proponents of the publication of the card index, for their part, emphasized the need to draw a line under the legacy left by the communist regime. In support of their position, they also referred to a rational benefit, pointing out that publishing the card index would deprive Russia of the ability to use this information to blackmail former KGB agents. ${ }^{10}$ As another important argument emphasized in favour of making the card index public was the right of victims to know the names of their persecutors, criticizing the peculiar approach of opponents who were more concerned about the moral suffering of former KGB agents and their relatives than about the rights of victims of persecution by the KGB.

The arguments used in these discussions deserve special attention, as they are relevant in the context of the tasks set in this study. On the one hand, it must be acknowledged that the supporters of the disclosure of the card index as well as their opponents referred to the experience of trauma in their arguments, thus showing that emotional-psychological experiences are given a certain role in addressing this issue. However, on the other hand, a more detailed analysis of these arguments reveals the weakness of the rhetoric of opponents of the card index disclosure. The argument about a possible witchhunt sounded like distrust of Latvian society; moreover, it was a speculation which, remembering Andrejevs's case, lacked a real basis. Talks on the need to find out the specific guilt and responsibility of each agent, mentioned in the card index, sounded hypocritical against the background of the still classified status of the agents' card index. The judgments of opponents of the disclosure of the card index on the reliability of its data deserve special attention here. If we accept Judith Herman's view, which links the recognition of trauma and development of its research to the interests of political forces, noting that there are always such political forces that seek to question this trauma and discredit its victims (Herman 1992), then here we can see a kind of analogy. True, in this case, the trauma itself was not questioned but rather considered the guilt of the culprits: maybe not all the culprits are in the card index, maybe their names are recorded in the card index without their knowledge and, finally, maybe they are not culprits at all? The fact that these shadows of doubt were produced only at those moments when the issue of disclosure of the card index became relevant - meanwhile, the card index was still being used to check the 
candidates for deputies - testified that the use of this argument had a specific purpose dictated by political interests. However, the most important thing that these discussions revealed was two statements that were not formulated openly but originated from their arguments. The judgments of the opponents of the publication of the card index, questioning the reliability of the card index and the guilt of the agents mentioned in it, indirectly made it clear that they also questioned the experience of the people mentioned in the reports of these agents: if there are no culprits, then there are no victims. Thus, the Latvian political authorities, as well as a part of society, indirectly confirmed that in the case of former KGB agents and victims of KGB persecution, they are not ready to accept the traumatic experience of an individual and a certain group of society in the general position of society. But perhaps the most frightening alogism that stemmed from the judgments of opponents of publishing the card index was the opinion that, in the case of the former KGB agents, the cause of the trauma - or at least a major trauma - is the disclosure of the fact of cooperation today, rather than a person's choice to cooperate with the KGB in the past. Such a view carried a distorted value orientation and, no less important, gave society a fairly clear signal that it was time to forget the past.

In the context of all of the above, it was not surprising that, thanks to a broad campaign of persuasion supported by the political authorities, the view that the publication of the card index of the former KGB agents should be postponed, prevailed in these discussions.

\section{TO UNDERSTAND AND/OR CONDEMN, THAT IS THE QUESTION}

The turning point followed in 2014, when the Latvian Government Commission for KGB Research was established. By public announcements and scientific conferences, the commission managed to mobilize the attention of the public, and in December 2018, due to public pressure, the card index of the former Latvian SSR KGB agents was published.

When assessing the importance of publishing the card index in public processes, various aspects can be highlighted. Undoubtedly, the publication of the card index gave the public one but very important benefit: it put an end to deliberate speculations and the unpleasant feeling that the government had something to hide from its citizens. Unfortunately, doubts and conjectures did not disappear completely. The main reason for this was the fact that in many cases the only evidence of a person's cooperation with the KGB was the agent's card without any indication of their specific activities. However, after weighing 
all the aspects, including the tedious 27-year debate, in this case we must agree with the expression: a horrible end is better than endless horror.

In Latvian society, the publication of the card index caused different reactions. ${ }^{11}$ The majority of the society, and especially its younger part, had an indifferent attitude towards it. There is an understandable explanation for this: people who are less than 40 years old today have not been objectively confronted with the reality of the Soviet repressive system and the activities of the KGB. In turn, the part of the society that is made up of people over 40 years old today remembers and understands the reality of the Soviet era well enough to, in most cases, receive the publication of the card index without a sharp emotional reaction. Therefore, the possible concerns that the publication of the card index could become a cause for a national trauma - snitches' superpower (Veidemane 2019a) - turned out to be unfounded. Against this background, a special group of society which has to be mentioned here were people who, after the publication of the card index, scrupulously scanned the list of agents in search of the names of their former or current colleagues, neighbours, and acquaintances. ${ }^{12}$ Their motives remained unclear: perhaps, they were driven by envy and a sense of inferiority (in response to the sometimes expressed idea that "fools did not work for the KGB"), but perhaps, they had found another 'keyhole' in the card index to look at the world. In any case, from the point of view of human psychology, the reaction of this group of society to the publication of the card index seemed the most traumatic.

If we talk about the reaction of the people whose names were mentioned in the KGB agents' card index, several groups can be distinguished here. Most of them, at least in public, did not comment on the fact. Others, and especially those who belonged to the intellectual elite of Latvia and had played a visible role in Latvia's independence restoration processes, expressed surprise and most often claimed that the agent's card was made without their knowledge. Thus, in addition to the already mentioned Inkēns, ${ }^{13}$ Ivars Godmanis, the former Deputy Chairman of the Popular Front of Latvia and the first Prime Minister of Latvia after the restoration of the country's independence, and Jānis Gavars, the former editor-in-chief of information programmes at the Latvian Television, reacted to the occurrence of their names in the card index of the former KGB agents. In turn, some others, including the former anchor-person of the TV weekly programme "Labvakar", Jānis Šipkēvics, and former basketball player Valdis Valters, reacted to their names in the card index with a sharp denial, expressing outrage at the denigration of their name (Vaidakovs 2019).

At the same time, among the people whose names were in the card index were those who publicly acknowledged the fact of cooperation, which they had 
agreed to as a result of the circumstances or the blackmail by the KGB. Astra Skrābane, philologist, French language and literature specialist and translator, openly and without seeking excuses spoke about her cooperation, admitting that today she is ashamed of her naivety (Kalve 2019). Composer and organist Aivars Kalējs, acknowledging his cooperation with the KGB and the fact that he had written reports, cited, as an excuse, the fact that he had tried in principle not to mention and thus protect nationally minded people (Kiršberga 2020). This argument-Yes, I cooperated, but I tried to protect and not to harm - can be found in the stories of several people about their cooperation with the KGB; most likely, with this explanation, they sought to resolve the cardinal dilemma between the fact of cooperation and their moral responsibility. Aleksej Grigor'ev, a graduate of the Faculty of Foreign Languages and an interpreter, went a little further and deeper in his judgments. Repenting the sin of cooperation with the $\mathrm{KGB}$, he spoke about pride, ${ }^{14}$ about the stupid idea that "you can play with the Devil [the KGB] and the Devil can be defeated". And right there, he continues: "Yes, subjectively we tried not to harm anyone, but we did not know how we were used" (Mikielsone 2019c).

The story that deserves special attention here is the confession of poet Jānis Rokpelnis, which he made public in December 2017, i.e., a year before the publication of the card index. According to him, as a freethinker, he was twice invited for an interview at the KGB, and only his father's name - his father Fricis Rokpelnis (1909-1969) was a co-author of the anthem of the Latvian SSRsaved him from the arrest. In 1985, J. Rokpelnis was offered to become an agent of the $\mathrm{KGB}$, and he agreed to this offer, explaining it with the desire to get to know the methods, used by the KGB, from the inside and then expose them publicly. ${ }^{15}$ Undoubtedly, from today's point of view, the explanation given by J. Rokpelnis sounds naive and even infantile, but we have no reason to doubt its truthfulness.

If we contemplate the reaction of the people whose names were mentioned in the KGB agents' card index, we can draw one important conclusion. Most of the people whose cooperation was motivated by coercion (imprisonment, blackmail) or professional activity (interpreters, bartenders) are ready to admit the fact of their cooperation with the KGB. In some cases, such a motive was family past; for example, the father's service in the Latvian Legion (a formation consisting mainly of ethnic Latvians, as part of the German army during the Second World War). ${ }^{16}$ The willingness of these people to confess can be partly explained by reasonable expectations that the public would more easily understand and accept this person's choice to cooperate with the KGB, but we cannot rule out the possibility that they themselves were actually going through their choices more deeply. In turn, those whose cooperation was more motivated by their career or 
other privileges are less willing to admit the fact of their cooperation because they do not have this socially acceptable explanation. In this regularity, the main dividing line which exists in the judgments of the agents themselves and the society in the assessment of former KGB agents is very clearly indicated: if an agent's cooperation had a publicly acceptable motive, it gave the cooperation some justification in the judgments of the agents themselves as well as in the judgments of the society. We can see the same dividing line in the public reaction to the willingness of the former KGB agents to confess and repent of their misdeeds. As an illustration, the public confession of J. Rokpelnis was accepted by the society without condemnation, whereas the confession made after the card index publication by the former rector of the University of Latvia, Mārcis Auziñš, who a few years earlier, in 2014, as a presidential candidate in Latvia, had denied his cooperation with the KGB, received a more critical response. This reaction - not to generalize but note it as a trend - reveals an important feature: it showed that in this case, for society, it is not the past faults that are more important, but their open recognition and regret.

On the other side of the 'Cheka Bags' were the subjects of the former KGB agents' reports, i.e., the people who were reported. This is a peculiar paradox, but a vast majority of them, like most of the former agents, adopted the publication of the card index in silence. It can be assumed that the main explanation for this silence was the 27-year indecision of the political authorities, which forced these people to muffle their painful experiences, and over time their memories faded. In addition, probably, a certain role has the fact that by this time, the efforts of the media and political circles in the public sphere had already conceptualized the image of the 'victim of the Cheka', which consisted of several better-known victims of political repression, and there was no room for new victims in this image. ${ }^{17}$

At first glance, the reaction of people about whom the agents' reports were written and who now expressed their opinions in public interviews seemed surprising: most of them, at least in public, did not identify themselves as victims. An explanation for this view is most likely to be sought in two circumstances. Firstly, the agents' reports of those still alive today most often date back to the 1970s and 1980s, i.e., to the time when the activities of the KGB had transformed from the methods of brutal repression of the 1940s and 1950s into more moderate methods of 'educational conversations'. Therefore, as the already mentioned Gailis's story showed, it was often difficult for a person to notice the influence of the KGB on their professional career or personal life. Secondly, the description of people in the agents' reports, who at that time were described as 'anti-Soviet', from the point of view of today's independent Latvia, rather looks like recognition or even praise. For illustration, we can mention 
the reports of agent Stirlitz (Normunds Grostiņš) about his fellow students at the Faculty of History and Philosophy, who had organized excursions to the First-World-War battlefields of the Latvian National Army and had spoken contemptuously about the Russians (Domburs \& Radovics 2020).

In most cases, this tolerance also characterized the judgments of the people mentioned in the reports, on the guilt and responsibility of the former KGB agents. Usually, when a person recognized the name of the agent who had reported them to the KGB, they reacted conciliatorily, using arguments: "such was the time", and "they had to write something". True, the question remains: How sincere is this reaction after 27 years of waiting? There was an interesting dualism in Lidija Lasmane-Doronina's judgments about the former KGB agents: while acknowledging that she did not condemn these people because the whole system was to blame and "we were all already forced to the knees", she immediately added that, having learned the name of the agent who had reported her, she could not forgive him (Meimane 2015). The exception is those people who, without being better known today, are looking for an explanation (or, perhaps, an excuse?) for their unfulfilled career expectations. One of them is composer and music teacher Atis Prieditis. Between 1980 and 1995, he was denied the opportunity to record his songs on the Latvian Radio, and therefore his songs remained unknown to a wider audience. He himself associates this with his 1980 song "Izkapts ābelel" (The Scythe in the Apple Tree), which in the Aesop's language was directed against the Soviet occupation of Latvia (the song's censors had mistakenly understood that it was directed against the German occupation) (Prieditis 2018: 68-69). As the most striking episode of his persecution, he noted a slanderous broadcast about him, prepared by the Latvian Television in the late 1980s. On the one hand, the aforementioned episodes of persecution cited by Prieditis make one think that the restrictions on his professional career had a broader ideological basis that reached beyond the authority of the KGB. On the other hand, however, his story contains a number of specific episodes of persecution - including the relocation of objects in his apartment during his absence and the connection of electricity to his apartment's gas stove (ibid.: 111-114) - which point to the KGB's working methods. Unfortunately, such methods of operation of special services are difficult to prove; moreover, in the case of an 'ordinary person' they sound incredible, so they are still scarcely mentioned in the public sphere.$^{18}$ For this reason, Prieditis has chosen a peculiar form of writing his memories - he writes books of fantastic content. In this respect, it can be argued that in the case of Prieditis, one of the characteristic features of a traumatic experience appears very clearly, when a person simultaneously wants to forget and make public his traumatic experience (Herman 1992: 1). 
But there is another unnoticed group of victims that should be considered within the framework of the topic of the KGB agents. These are people who rejected KGB's offer of cooperation and did not become agents. The experience of such recruitment is described by several people, but the story of the wellknown Latvian photographer Gunārs Binde is emotionally the strongest. In his judgments, he is harsh: the KGB's attempts to recruit "actually broke my life and myself" (Meiere 2020). Recalling the blackmail and intimidation used in recruiting, he describes these methods as disgusting. One of the strongest experiences, in his judgments, was the fear of the possible consequences of refusal: what would happen to me and whether my family would suffer - these were the questions he asked himself. However, another episode deserves the main emphasis in his story. Binde describes as psychologically painful for him the warning made by the recruiters at the very beginning about keeping the meeting and conversation a secret; after a long silence, he nevertheless decided to tell his wife about it. This small episode expresses the main moral postulate that cooperation with the KGB was a choice between loyalty to the state and loyalty to one's family, relatives, and friends. It is this choice that is the first and also the main thing which made people's cooperation with the KGB immoral.

When assessing the different public reactions to the publication of the card index, two conclusions should be emphasized. First, the generally tolerant reaction of the public and the media to the revelations of the former agents is certainly noteworthy. It is significant that during the year after the publication of the card index, only one publication has appeared (Fedosejeva 2019), which talks about the "snitches' fault" and the fault in general. This tolerance could be welcomed if there was no doubt that in this case there was no fear of open conversation. Secondly, the numerical ratio between the relatively large number of stories of the former KGB agents and the relatively small number of stories of the KGB persecution victims, which appeared in media publications and interviews after the publication of the card index, is striking. Moreover, as philosopher Ilze Fedosejeva points out (ibid.), this disproportionate balance is also reflected in the attention of society, which focuses more on the perpetrators than on the victims; she herself explains this with practices established by Christianity and accepted in secular society, which focus on sin and forgiveness.

In addition to the specific aspects of the relations between agents and victims, the card index of former KGB agents, published in 2018, brought up another question: how to evaluate the cooperation of people with the KGB, so that you do not have to rewrite the history of restoring the country's independence?

The first to give a reason for asking such a question was Edmunds Johansons, the last chairman of the Latvian SSR KGB: in his speech to the Saeima on 23 August 1991, he mentioned that 37 deputies of the Saeima, who had worked 
for the KGB or cooperated with the KGB, had voted for the restoration of Latvia's independence (Taurēns 2015: 400-401). In subsequent years, this figure changed, but that did not change the fact itself. ${ }^{19}$ But this is not only a matter of formal voting, but also of advancing the awakening processes. Among the people whose names were found in the card index of the former KGB agents were not only all the three (!) anchor-persons of the television programme "Labvakar" and the first head of the Latvian government; Juris Ziemelis (1941-1988), a member of the human rights group "Helsinki-86", Arvīds Ulme, head of the Environmental Protection Club founded in 1988, Valts Titavs, one of the founders of the Latvian National Independence Movement, and Mavriks Vulfsons (1918-2004), author of a public speech condemning the Molotov-Ribbentrop Pact, which caused a wide public resonance in 1988, were also in the agents' card index. The role of these people in the awakening processes was significant enough to give rise to speculations about the influence of the KGB on the progress of the awakening processes.

Today, in the judgments of the Latvian political elite, any assumptions about the possible role of the KGB in advancing the awakening processes are assessed as "nonsense", ${ }^{20}$ leaving unnoticed the obvious contradiction of such a judgment with the overall assessment of the role of the KGB. On the one hand, when describing the processes in the society in the mid-1980s, we are talking about the KGB's comprehensive public control and ability to influence the fate of people (the last large-scale arrests of dissidents in the Latvian SSR took place in 1983). On the other hand, in the judgments on the awakening processes, practically all politicians of the early 1990s, including Dainis İvāns, the first leader of the Popular Front of Latvia, agree that, despite the KGB's awareness, the KGB was unable to seriously influence the process of restoring independence (Īvāns 1995: 180-181). It is difficult to judge whether this contradiction in assessing the role of the KGB will persist or whether it will be resolved at some point, but it is clear that the link of several prominent leaders of the awakening with the KGB has been and remains one of the reasons for the reticence of the political authorities in overcoming the legacy of the KGB in Latvia.

\section{CONCLUSIONS}

Decommunization of all the countries of the former so-called Soviet bloc in Eastern Europe was an important process that was necessary for the successful development of the country. An important part of this process was the identification of employees and agents of the security services of the former Soviet regime and the assessment of their activities. Most Eastern European countries 
have chosen the lustration path, allowing former employees and agents of the secret services to voluntarily submit an application and report on their activities. Latvia chose another path, publishing the card index of all former Latvian SSR KGB agents without any derogation. Compared to the choice of other countries, the path chosen by Latvia is the most radical and, in a sense, perhaps the cruellest, but it cannot be said with certainty that any of these choices was the best or the most correct. The main argument in favour of Latvia's choice is that by publishing the names of the agents mentioned in the card index, each of these people is given the opportunity to respond publicly and explain their motives.

Unfortunately, in the case of Latvia, the publication of the card index of former agents has not become the basis for a balanced assessment of the past, nor for reconciliation of different groups in society. There are several explanations for this, but the most frequently mentioned reason in the public debate is that the publication of the card index was belated, and it should have been made public a long time ago. And the main reason for this delay lies in the stance of Latvian political authorities, which, after taking over the card index in 1991, made the issue of the former KGB agents a hostage of their political interests. The indecision of political authorities was made even more unpleasant by the fact that, speaking loudly about the possible division of society and a possible witch-hunt, political circles used it for behind-the-scenes manipulations, the most striking example of which was a piece of media news in 2017 about the disappearance of the court case on establishing the fact of cooperation between Godmanis and the KGB from the court archives (Bērtule 2017). The position of the political authorities - indecision, judgments about the possible witch-hunt, and concerns about the possible moral suffering of former KGB agents and their relatives - gave a clear enough signal to the public that, from the point of view of political authorities, it was time to forget everything. And here it is necessary to make one broader and more significant generalization. If we turn again to the already mentioned work of Hirschberger, in which he describes the differences in the perception and identification of collective trauma between victims and persecutors, then a harsh conclusion must be drawn: consciously or unintentionally, yet objectively, as regards collective trauma, in Latvia during these 27 years the perception of persecutors has dominated over the perception of victims. In the case of Latvia, we see two main features that Hirschberger attributes to the persecutors' position: the desire to look at the former KGB agents in a positive light, by questioning their guilt and responsibility, and the desire "to close the door on history and never look back" (Hirschberger 2018).

In this situation, it is not surprising that after 27 years of hesitation, most people, at least in public space, have already silenced their traumatic experiences and forced them out of their daily consciousness. But silence is not the 
path to reconciliation in society. Moreover, this silence, tolerance of society and the fear of intellectuals of offending someone did not allow us to start a serious discussion about assessing our common past and the responsibility of each person. Therefore, the question of how to evaluate people's cooperation with the KGB still remains open. It is clear that there is a difference between a KGB agent who dealt with the prevention of economic crimes, and a KGB agent who wrote reports on 'kitchen conversations'. Just as it is clear that there is a difference between a KGB agent who applied for cooperation on a voluntary basis and a KGB agent who was forced to cooperate for various reasons. However, recognizing these differences between different agents, a new threat emerges: such a view may lead to a paradoxical conclusion about the devilish $\mathrm{KGB}$ and the innocent and even good KGB agents. In addition, there is another aspect of this silence that historian Daina Bleierehas noted: acknowledging that reluctance to speak is the main problem of the 'Cheka Bags', she points out that those born in independent Latvia are not able to understand how the totalitarian system worked and why it is terrible if those who have experienced it do not talk about it honestly (Mikelsone 2020).

Where to look for a solution in this situation? In terms of historical truth, it may be necessary to allow time to pass so that the memories of the Soviet regime will remain only in 'parchments' and the issue of assessing the activities of the KGB agents will become only a "domain of professional historians" (Neal 1998: X). Unfortunately, in terms of trauma and public reconciliation, no such answer is possible. The already mentioned Atāls in an interview, acknowledging that in order not to fray his life and soul, he had forgiven his abusers, admitted: "As I wrote the book, I felt like I had thrown all the grievances in the trash" (Jundze 2018). This recognition formulates an important conclusion; namely, in today's situation people can seek reconciliation only with themselves and within themselves.

\section{ACKNOWLEDGEMENTS}

This article was written within the framework of the project "Interaction between the individual, the society and the state in the process of the history of Latvia: Conflicting values and formation of shared values during historical turning points" (project no. VPP-IZM-2018/1-0018). 


\section{NOTES}

1 A striking example is the so-called Red Latvian Riflemen, who were made a symbol of heroism in Soviet Latvia but have been forgotten after the restoration of independence (a certain symbolic significance, in this context, can be seen in the fact that the Red Latvian Riflemen Museum in Riga, opened in 1970, was closed in the early 1990s and in 1993 the Museum of Occupation of Latvia was opened on its premises).

2 The national heterogeneity of Latvian society is especially evident in the annual events of 9 May in Riga, when the predominantly Russian-speaking part of Latvian society celebrates Victory Day, while for Latvians it is mostly a date associated with the restoration of Soviet occupation in Latvia.

3 The term 'political authorities', in this case, must be understood as official institutions of state authority and public officials.

4 There are various explanations for differences in the number of the publicly mentioned agent cards: Indulis Zālite, the former head of the Centre for Documentation of the Consequences of Totalitarianism, who administrated the agents' card index until the end of 2018, explains it as a misunderstanding, assuming a calculation error in the past (Veidemane 2019b); meanwhile, already from the mid-1990s onwards guesses about the possible removal of agents' cards from the card index appeared in the media (Mikelsone 2019b).

5 The author of this production was a well-known theatre director, Alvis Hermanis, who, as he admitted after the publication of the card index, also had his own experience in relations with the KGB: his father Voldemārs Hermanis, who since 1985 had been the editor-in-chief of a newspaper for Western Latvians, Dzimtenes Balss (Homeland Voice), was mentioned in the KGB agents' card index, while A. Hermanis himself had come to the attention of the KGB in the first half of the 1980s due to his free-thinking and had been admitted to a psychiatric hospital for refusing to join the Soviet army (the war in Afghanistan had begun at that time) (Raudseps 2019b).

6 Such a description of the Soviet system was given by publicist Marina Kostenecka, who at the end of the 1980s had actively participated in Latvia's independence-restoring processes and faced KGB persecution; by that characterization she substantiated her opposition to the card index publication (Raudseps 2019a).

7 Nikita Petrov, vice-chairman of the Memorial Organization for the Study of Totalitarianism Crimes in Russia, admits that people could refuse to cooperate with the KGB or stop cooperating later, and one such example in Latvia was film director Rolands Kalniņš, who was recruited in 1975 but excluded in 1978 from among the agents for non-cooperation (Mikelsone 2019c).

8 This judgment is based on the assumption that documents of the LSSR KGB were partly taken to Russia before Latvian independence restoration, but there are differences in the guesses about the proportion of documents taken out and those left in Latvia: extreme critics of the credibility of 'Cheka Bags' claimed that the KGB agents' files, taken over by Latvia in 1991, were left here with some special purpose or were a forgery altogether. 
9 The last attempt initiated by political circles to suspend the publication of the card index was an expert working group, established in 2018, which on 16 August 2018 published its conclusions on the inadmissibility of the card index publication; commenting on the findings of the working group, one of its members, Bishop Emeritus Pāvils Brūvers, in addition to the previous ones, noted as another argument a possible monetary compensation that people mentioned in the card index could demand from the Latvian state, strictly stating that in any case "publishing such a list would be a crime against the nation, specific people and the state" (Veidemane 2018).

${ }^{10}$ As an example of the blackmail of former KGB agents, to 'stimulate' their activities in favour of Russia, we can mention the case of Herman Simm, a former chief of the Estonian Defence Ministry's security department, which, according to Ivo Juurvee, an adviser at the National Security and Defence Coordination Unit of the Estonian Government Office, was a former KGB agent and had not acknowledged this fact after the restoration of Estonia's independence (Semjonova 2020).

11 To illustrate the variety of this reaction and to emphasize the presence of healthy cynical sarcasm in it, one tweet published immediately after the card index publication can be noted here: Russian dictionaries will be bought out in bookstores tomorrow [agent cards were drawn up in Russian], but the day after tomorrow - hay forks and torches in Depo (a household goods store).

12 This public reaction was also encountered by the author of this article, and in one case it was related to the fact that there was a person in the card index of the former KGB agents whose name was identical to the name of the author.

${ }^{13}$ In 2002, speaking about his name being in the card index, Inkēns acknowledged the fact of recruitment, but explained it as recruitment to the perspective, to the future; therefore, he did not perform any practical activities as an agent (Mille 2002: 29-31).

${ }^{14}$ One of the sins in Christianity.

${ }^{15}$ By the way, J. Rokpelnis mentioned Estonian novelist Arvo Valton as the only case when he was given a specific task to find out the thoughts of his fellow writers, but he refused this task (Veidemane 2017).

${ }^{16}$ One of the best-known examples here is Imants Lešinskis (1931-1985), head of the Latvian Committee for Cultural Relations with Countrymen Abroad, later an employee of the UN Secretariat in New York, a double agent of the USSR and US secret services, who fled to the USA in 1978. His cooperation with the KGB as an agent began in 1956, and as a recruitment incentive, the KGB had used the fact that Lešinskis's father had been drafted and served in the German army in 1944 (Lešinskis 2017: 37-38).

${ }^{17}$ As an illustration, in 2016 a wide public resonance was caused by the judgement given by the Latvian Prosecutor's Office that involuntary psychiatric treatment of Gederts Melngailis, arrested in 1983 for "anti-Soviet activities", was "justified, mandatory, and legal" (Krēsliṇ̌s 2016). The same applies to already mentioned Atāls, to whom Latvian state refused to grant the status of a repressed person on the grounds that he had been tried according to the Criminal Code (Jundze 2018).

${ }^{18}$ A confirmation that A. Prieditis's experience is not a 'sick imagination' but a real method of special services, is given by the television documentary The Stasi: Behind 
the Berlin Wall (2018) in the cycle Forbidden History, which tells about the operation of the Ministry for State Security (Stasi) of the former German Democratic Republic.

${ }^{19}$ After the card index publication, the magazine $I r$ found out that the card index contained the names of 17 deputies of that time, of whom 15 had voted for Latvia's independence. In this case I am more interested in another aspect: when journalists wanted to interview these 15 former deputies in 2019, it turned out that three of them were already dead, four refused the interview and only four of the eight, who agreed to be interviewed, acknowledged their cooperation with the KGB (Mikelsone 2019c).

${ }^{20}$ Such an assessment was given in 2019 by Indulis Zālīte, former head of the Centre for Documentation of the Consequences of Totalitarianism (Veidemane 2019b).

\section{REFERENCES}

Andrejevs, Georgs 1994. Tā, tas nu irpateikts! Atklāta vēstule maniem vēlētājiem, draugiem un 5. Saeimas deputātiem. [So, It Is Said Now! An Open Letter to My Voters, Friends and Deputies of the 5th Saeima.] Diena, 28 May, pp. 17-19.

Atāls, Valdis 2018. Elles debesis. [Hell's Sky.] Riga: Dienas Grāmata.

Dimitris, Juris 2019. Izlūkošanas laboratorija: Rīga-Monreāla 1969. [Intelligence Laboratory: Riga-Montreal 1969.] Riga: SIA Goldberg Trust.

Gailis, Māris 1997. Varas tehnoloǵija. [Technology of Authority.] Riga: Jumava.

Gūtmane, Zanda 2019. Totalitārisma traumu izpausmes Baltijas prozā. [Manifestations of Totalitarianism Traumas in Baltic Prose.] Riga: Latvijas Universitātesliteratūras, folkloras un mākslas institūts.

Herman, Judith 1992. Trauma and Recovery: The Aftermath of Violence-from Domestic Abuse to Political Terror. New York: Basic Books.

Īvāns, Dainis 1995. Gadījuma karakalps. [Casual Soldier.] Riga: Vieda.

Johansons, Edmunds 2006. Čekas G̦enerāla piezīmes: Atmoda un VDK. [Cheka General's Remarks: Awakening and KGB.] Riga: 1991. gada barikāžu dalībnieku biedrība.

Jundze, Arno 2018. Valdis Atāls: Elles debesis. [Valdis Atāls: Hell's Sky.] Neatkarīgā, 5 September, pp. 12-13.

Krēsliṇš, Uldis 2016. Neizprotama padomju pagātnes atbalss. [An Incomprehensible Echo of Soviet Past.] Latvijas Avize, 9 August, pp. 4-5.

Lešinskis, Imants 2017. Starp divām pasaulēm: Kalpības gadi un citi raksti. [Between Two Worlds: Years of Services and Other Articles.] Riga: Domas spēks.

Levi, Primo 1959. If This Is a Man. New York: Orion Press. Available at http:// msmulhollandonline.weebly.com/uploads/7/9/3/4/7934993/primo_levi_if_this_ is_a_man.pdf, last accessed on 7 July 2021.

Meiere, Agnese 2020. Esmu visīstākais malēnietis. [I Am the Truest Malenietis.] Ievas Stāsti, No. 5, pp. 18-22.

Meimane, Ineta 2015. Dvēseles dzidrums. [Clarity of Soul.] Ievas Stāsti, No. 15, pp. 8-13.

Melnais, Pēteris 1993. Slepeni: Par čekas darb̄̄bu R̄̄gā 1960.gados pret latviešiem. [Secretly: About the Actions of Cheka against Latvians in Riga in the 1960s.] Riga: Junda. 
Miķelsone, Māra 2019a. Čekas maisu CV. [Cheka Bags' CV.] Ir, No. 45, pp. 18-23. Available at https://ir.lv/2019/11/06/cekas-maisu-cv/, last accessed on 8 July 2021.

Miḳ̌elsone, Māra 2019b. Čekas maisu "mistika". [Cheka Bags' "Mysticism”.] Ir, No. 19, pp. 14-16. Available at https://ir.lv/2019/05/08/cekas-maisu-mistika/, last accessed on 8 July 2021.

Miḳelsone, Māra 2019c. Spēle ar velnu. [Game with the Devil.] Ir, No. 46, pp. 14-19. Available at https://ir.lv/2019/11/13/spele-ar-velnu/, last accessed on 8 July 2021.

Miķelsone, Māra 2020. Melns nav melns, balts nav balts. [Black Is Not Black, White Is Not White.] Ir, No. 4, pp. 14-19. Available at https://ir.lv/2020/01/29/melns-navmelns-balts-nav-balts/, last accessed on 8 July 2021.

Mille, Astra 2002. Labvakar, Edvīn Inkēn: Varas fizioloǵija. [Good Evening, Edvin Inken: Physiology of Authority.] Riga: Atēna.

Neal, Arthur G. 1998. National Trauma and Collective Memory: Major Events in the American Century. New York: M.E. Sharpe.

Priedītis, Atis 2018. Gan jau rìts mūs atradīs. [Let Morning Find Us.] Riga: n.p.

Raudseps, Pauls 2019a. Aizstāvutos, kurus vajā. [I Defend Those Who Are Being Persecuted.] Ir, No. 39, pp. 28-32. Available at https://ir.lv/2019/09/25/aizstavutos-kurus-vaja/, last accessed on 8 July 2021.

Raudseps, Pauls 2019b. Dzīves žanrs ir traǵikomēdija. [The Genre of Life Is a Tragicomedy.] Ir, No. 15, pp. 28-32. Available at https://ir.lv/2019/04/10/dziveszanrs-ir-tragikomedija/, last accessed on 8 July 2021.

Ruks, Māris 2011. 20. gadsimta latvietis Gunārs Astra. [20th-Century Latvian Gunars Astra.] Riga: Antava.

Stukāns, Juris 2015. Tiesu nolēmumu analīze lietās par sadarbības ar LPSR Valsts drošības komiteju fakta konstatēšanu. [Legal and Procedural Aspects Establishing the Fact of Collaboration with the KGB.] In: K. Jarinovska (ed.) Totalitärisma sabiedrības kontrole un represijas (zinojumi starptautiskajā zinātniskajā konferencē Totalitārisma sabiedrības kontrole un represijas: dokumentu izpēte un tās metodoloǵija 2015. gada 15., 16. un 17. decembrī Liepājāa). Autoru kolektīus K.Jarinovskas zinātniskajā redakcijā. VDK zinātniskās izpētes komisijas raksti, 1. sēj. Riga: LPSR Valsts drošības komitejas zinātniskās izpētes komisija, Latvijas Universitātes Latvijas vēstures institūts, pp. 116-146. Available at https:// www.lu.lv/fileadmin/user_upload/lu_portal/projekti/vdkkomisija/VDKkomisija_ raksti_1sejums_Totalitarisma-sabiedribas-kontrole-un-represijas_2016-0330marts.pdf, last accessed on 8 July 2021.

Šāberte, Baiba 2006. 1991: Nepabeigtā mozaīka. [1991: Unfinished Mosaic.] Riga: n.p. Taurēns, Jānis 2015. Zinātniskā un sabiedriskā polemika par LPSR Valsts drošîbas komitejas dokumentāro mantojumu. [Discussions on the Problem of the Heritage of the KGB since the Re-establishment of the Independence of the Republic of Latvia.] In: K. Jarinovska (ed.) Totalitārisma sabiedrības kontrole un represijas (ziñojumi starptautiskajā zinātniskajā konferencē Totalitārisma sabiedrības kontrole un represijas: dokumentu izpēte un tās metodoloǵija 2015. gada 15., 16. un 17. decembrī Liepājā). Autoru kolektīvs K.Jarinovskas zinātniskajā redakcijāa. VDK zinātniskās izpētes komisijas raksti, 1. sēj. Riga: LPSR Valsts drošības komitejas zinātniskās izpētes komisija, Latvijas Universitātes Latvijas vēstures institūts, pp. 399-442. Available at https://www.lu.lv/fileadmin/user_upload/lu_ 
portal/projekti/vdkkomisija/VDKko misija_raksti_1sejums_Totalitarismasabiedribas-kontrole-un-represijas_2016-03-30marts.pdf, last accessed on 8 July 2021.

Taurēns, Jānis 2017. LPSR Valsts drošības komitejas ārštata darbinieku, aǵentu un informatoru identitātes un tiesas procesi par sadarbības fakta ar VDK konstatēšanu: apspriešana presē un publiskajā telpā. [Identities of the LSSR KGB Agents and Informers and the Court Procedures for Establishing the Fact of Collaboration with the KGB: Discussions in the Press and among the Public.] In: K. Jarinovska (ed.) Lielais Brālis Tevi vēro: VDK un tās piesegstruktūras (ziñojumi starptautiskajā zinātniskajā konferencē 2016. gada 11., 12. un 13. augustā R̄̄gā). Autoru kolektīvs K. Jarinovskas zinātniskajā redakcijā. VDK zinātniskās izpētes komisijas raksti, 4. sēj. Riga: LPSR Valsts drošības komitejas zinātniskās izpētes komisija, Latvijas Universitāte, pp. 65-131. Available at https://www. lu.lv/fileadmin/user_upload/lu_portal/projekti/vdkkomisija/VDK-izpetes-rakstukrajums-4sejums_2017-12-30decembris_LielaisBralisTeviVero_VDK-un-taspiesegstrukturas_ISBN_978-9934-8587-7-2.pdf, last accessed on 8 July 2021.

Vaidakovs, Juris 2019. Arī viṇi ir čekas maisos. [They Are Also in Cheka Bags.] Kas Jauns, No. 1, pp. 8-13.

Veidemane, Elita 2018. Brūvers: Čekas maisu publiskošana saduļ̧̣os gaisu. [Bruvers: Disclosure of Cheka Bags Will Make Muddy Air.] Neatkarīgā, 1 October, pp. 6-7. Available at https://nra.lv/latvija/259058-bruvers-cekas-maisu-publiskosanasadulkos-gaisu.htm, last accessed on 8 July 2021.

Veidemane, Elita 2019a. Latvija - stukaču lielvalsts? Pārspīlējumi un neziṇa. [Latvia - A Snitches' Superpower? Exaggeration and Ignorance.] Neatkarīgā, 11-13 January, pp. 6-7.

Veidemane, Elita 2019b. Zālīte: VDK priekšsēdētājs uzdeva "sakārtot lietas". [Zalite: The Chairman of the KGB Instructed to "Arrange Things".] Neatkarīgā, 23 April, pp. 6-7. Available at https://nra.lv/latvija/278819-zalite-vdk-priekssedetajsuzdeva-sakartot-lietas.htm, last accessed on 8 July 2021.

\section{INTERNET SOURCES}

Bērtule, Anete 2017. Tiesa dzen pēdas Godmaṇa VDK tiesvedības lietai un cer to atrast. [The Court Is Following in the Footsteps of the Godmanis KGB Litigation Case and Hopes to Find It.] Lsm.lv, 9 November. Available at https://www.lsm.lv/ raksts/zinas/latvija/tiesa-dzen-pedas-godmana-vdk-tiesvedibas-lietai-un-cer-toatrast.a256828/, last accessed on 9 July 2021.

Domburs, Jānis \& Radovics, Viesturs 2020. "Maisi vaḷā": Aǵents Štirlics ziṇo par vēsturniekiem un pagrīdes porno seansiem; Grostiņš: "Ar VDKneesmu sadarbojies”. [Bags Are Open: Agent Stirlitz Reports on Historians and Underground Porn Seances; Grostiņš: "I have not cooperated with the KGB".] Delfi.lv, 7 February. Available at https://www.delfi.lv/delfi-tv-ar-jani-domburu/raksti/maisi-valaagents-stirlics-zino-par-vesturniekiem-un-pagrides-porno-seansiem-grostinsar-vdk-neesmu-sadarbojies.d?id=51861027, last accessed on 9 July 2021. 
Fedosejeva, Ilze 2019. Par stukaču vainu domājot: 1. un 2. daḷa. [Thinking about Snitches' Fault: Part 1 and 2.] Satori.lv, 4 October, 5 November. Available at https://satori. lv/article/par-stukacu-vainu-domajot-1-dala, https://satori.lv/article/par-stukacuvainu-domajot-ii, both last accessed on 9 July 2021.

Hirschberger, Gilad 2018. Collective Trauma and the Social Construction of Meaning. Frontiers in Psychology, Vol. 9, August 10. https://doi.org/10.3389/fpsyg.2018.01441.

Kalve, Jānis 2019. Pašlustrācija: Tulkotāja un pasniedzēja Astra Skrābane. [SelfLustration: Translator and Teacher Astra Skrabane.] Lsm.lv, 15 November. Available at https://www.lsm.lv/raksts/kultura/kulturtelpa/paslustracijatulkotaja-un-pasniedzeja-astra-skrabane.a335806/, last accessed on 9 July 2021.

Kiršberga, Sandra 2020. Pašlustrācija: Komponists un ērǵelnieks Aivars Kalējs par sadarbību ar VDK. [Self-Lustration: Composer and Organist Aivars Kalejs about Cooperation with the KGB.] Lsm.lv, 3 January. Available at https://www.lsm.lv/ raksts/dzive--stils/vesture/paslustracija-komponists-un-ergelnieks-aivars-kalejspar-sadarbibu-ar-vdk.a342714/, last accessed on 9 July 2021.

Semjonova, Ella 2020. Ko darīt ar komunistiskā laika arhīviem un aǵentiem? Četru valstu pieredze. [What to Do with Communist Era Archives and Agents? Experience of Four Countries.] Lsm.lv, 2 January. Available at https://www.lsm.lv/raksts/ zinas/arzemes/ko-darit-ar-komunistiska-laika-arhiviem-un-agentiem-cetruvalstu-pieredze.a343463/, last accessed on 9 July 2021.

Veidemane, Elita 2017. Jānis Rokpelnis: Es biju VDK ağents. [Janis Rokpelnis: I Was an Agent of the KGB.] Nra.lv, 27 December. Available at https://nra.lv/latvija/232634janis-rokpelnis-es-biju-vdk-agents.htm, last accessed on 9 July 2021.

Uldis Krēsliṇš is Researcher at the Department of 20th Century Research of the Institute of Latvian History at the University of Latvia. His main research area is the political history of Latvia in the twentieth century. As a member of the Scientific Commission for Research of the KGB of the Latvian SSR, he has authored several publications on the activities of the former KGB.

uldis.kreslins@lu.lv 